\title{
The New Testament and Homosexuality? Part 1: The Social System behind Romans 1
}

\author{
B J Malina ${ }^{1}$ \\ (Creighton University)
}

\begin{abstract}
The New Testament and Homosexuality? Part 1: The Social System behind Romans 1
\end{abstract}

In this, the first of two parts of a continuous argument, the focus falls on what Paul meant by his statement in Romans 1 about same-gender sexual relations. The social system within which and from which his statements had meaning is considered. The second part of this argument, to appear in Verbum et Ecclesia 23 (2) 2002, looks more closely at the various traditions that could have influenced Paul's thinking, and draws conclusions to the developed argument on the prevalence of homosexuality in the New Testament era.

\section{INTRODUCTION}

The question mark in the title is intended to express both surprise and puzzlement. The surprise derives from the realisation that any historically minded person in the twenty-first century would expect to find anything at all about homosexuality in the New Testament. After all, the terms "homosexuality", "heterosexuality", and "bisexuality" are nineteenth-century inventions meant to label the dawning nineteenth-century awareness of persons as subjective, psychological centres of awareness, as individualistic. Individualism, in the sense the term is currently used in the United States, is the outcome of that rearrangement of human perceptions and experience called Romanticism (also known as postmodernism today) $)^{2}$. Homosexuality describes a more or less permanent

1 Prof Bruce Malina is an honorary professor of the Department of New Testament of the University of Pretoria. Permission for the publication of this article was given by the author.

${ }^{2}$ Homosexuality, that is, same-gender sexual orientation, was not of concern in antiquity. It is of recent vintage, emerging with the rise of economies as focal social institution and the challenges in lifestyle brought on by the Industrial Revolution and Romanticism. With social interest turning to persons as individuals and their individualism, sexual orientation was disjoined from gender. "Though the term 'individualism' is relatively recent, a nineteenth-century coinage, the existence of individuals has long seemed to be a constitutive, universal element in the natural structure of human experience and hence more the basis than the object of historical 
psychological state entailing the sexual orientation of individuals toward persons of the same biological gender. The nineteenth-century awareness that some persons were homosexual is indeed something new, since before that period all evidence indicates that persons were anti-introspective and not psychologically minded at an. That means that even if persons were "homosexual," the same-gender sexual orientation would be ascribed to ethnic custom, popular custom, traditional convention, or some other group-specific social practice ${ }^{3}$. This was surely the case for the world of Jesus and the world of Paul.

Consider an experience we would consider most subjective, personal, and psychological - dreams. An early-second-century book of dream analysis, the Oneirocritica by Artemidoros of Daldis, shows no evidence of interest in internal, psychological states at all. "The significant messages from the Artemidoran soul concern external matters of fact, not internal feelings, whereas the Freudian soul is trying to talk about suppressed wishes" (Winkler 1990:26). This lack of concern for the psychological is equally evident in biblical dreams (e.g., the many dreams in Genesis or Matthew 2; see Pilch 1997).

Some would argue that, human nature being what it is, there must have been homosexuals in the ancient world for Paul to condemn their behaviour in Romans 1. If human nature means that dimension of human beings that is entirely the same for all human beings, such as anatomy, biological processes, and the subjects studied by the "natural" sciences

investigation. But the belatedness of the general term for the phenomenon of individuals should make us wary of assuming the stable existence of individualism as a category of human life..." (Greenblatt 1986:32, cited by Halperin 1990:159). For the recent individualistic cultural script in comparison with majority collective societies in the world today, see Malina 1986; 1994; Triandis 1990.

3 For example, the seer of the Sibyllines notes: "More than any men they (Israelites) are mindful of the purity of marriage. Nor do they hold unholy intercourse with boys, as do the Phoenicians, Egyptians and Latins, and spacious Hellas and many nations of other men, Persians and Galatians and all Asia transgressing the holy law of the immortal God which he ordained" (Sib. Or 3:594-600, Charles 1913); similarly Josephus: "What reason can there be why we should desire to imitate the laws of other nations, while we see they are not observed by their own legislators? And why do not the Ladomonians think of abolishing that form of their government which suffers them not to associate with any others, as well as their contempt of matrimony? And why do not the Eleans and Thebans abolish that unnatural and impudent lust, which makes them lie with males?" (Against Apion 2.37.273, Whiston); or the Letter of Aristeas, contrasting Israel and "most other" ethnic groups: "For most other men defile themselves by promiscuous intercourse, thereby working great iniquity, and whole countries and cities pride themselves upon such vices. For they not only have intercourse with men but they defile their own mothers and even their daughters. But we have been kept separate from such sins" (Ep. Aristeas 152, Charles 1913). 
of chemistry, biology, and physics, then one would have to admit that such human nature existed in the first-century Mediterranean world. Human nature in the sense of nature studied in the natural sciences refers to how human beings are entirely the same through time and over space. Social interpretations of human nature, however, take this entirely-thesame dimension of human beings and endow it with specific meanings and feelings within a well-defined social system. For example, all human beings the world over are females or males; but the meanings attached to being female or male are quite different in specific social groups. And all human beings the world over have offspring; but the significance of a first child over against other children, of male babies over against female babies, is quite distinct in different human societies. The area covering the way human groups interpret identical human nature is called the social or the cultural. While human beings might be the same the world over according to the perspectives of the natural sciences, what counts as proper human behaviour can be explained in radically different ways according to the perspectives of specific cultures.

Human beings as we find them across time and space are entirely the same (nature), entirely different (unique personality, a Romantic concept), and somewhat the same and somewhat different (cultural interpretation of specific groups) at the same time (see Malina 1993). All social "isms" involve the identification of human nature with a specific culture or dimension of that culture (e.g., racism, sexism, feminism, etc.). Perhaps this is the underlying cause of the difficulties attending the evaluation of homosexuality in contemporary Roman Catholic moral theology. Is homosexuality a cultural perception specific to one or another society? Is the assessment of sexual orientation inbuilt in the nature of human beings (demonstrable by natural sciences) or the result of enculturation within a specific social system?

To appreciate what Paul meant by his statement in Romans 1 about same-gender sexual relations, one must look at the social system within which and from which his statements had meaning (see Halliday 1978; Malina 1991; 1996).

\section{WHAT DID PAUL MEAN?}

Language expresses meanings from a social system. Roman Catholic biblical interpreters have been directed more than once to discover what an author said and meant to a specific audience in a specific time and culture (Dei Verbum 12: "Interpreting the Bible in the Church"). Paul's statements were directed to a first-century Mediterranean audience, com- 
posed largely of Judeans ${ }^{4}$. His mode of argument, use of Israel's Scripture, concerns about his own ethnos (people), and his typical Israelite ethnocentrism all point to a Judean social context. This is surely the case for the document known as the Letter to the Romans. While Paul addresses "all God's beloved in Rome" (1:7), not once does he mention "Romans". Rather the letter is directed to Judeans, ethnic Israelites in Rome, who have accepted Jesus of Nazareth as Israel's Messiah soon to come. There are a few non-Israelites in the group (Rom 11:13: Paul is an apostle to Judeans in Gentile regions; the view of Eph 3:6 is post-Pauline). But they are not Paul's major concern. Rather the letter made sense to Israelite emigrés forming the rather small Jesus groups found largely in the Judean immigrant quarter (Trastevere) of first-century Rome. From a Judean ethnocentric perspective what characterised Gentiles, a word meaning everybody but Israelites, was idolatry. Non-Israelites behaved as they did because of their idolatry. Judeans might be anything, but it was a matter of ethnic pride not to waver in allegiance to the deity of the ethnic group, the God of Israel. The Judean focal value, a value espoused by Jesus-group members as well, was no mixture with outsiders ${ }^{5}$. With this value in mind, Paul addresses his fellow Israelite Jesus-group members in Rome.

After finishing the introductory niceties of the letter with its theological thematic (1:1-17), Paul launches into what seems to be standard Judean accusations against Gentile idolatry. The "us" against "them" language indicates this:

"For the wrath of God is revealed from heaven against an ungodliness and wickedness of those who by their wickedness suppress the truth. For what can be known bout God is plain to them, because God has shown it to them. Ever since the creation of the world his eternal power and divine nature, invisible though they are, have been understood and seen through the things he has made. So they are without excuse; for though they knew God, they did not honour him as God or give thanks to him, but they became futile in their thinking, and their senseless minds were darkened. Claiming to be wise, they became fools; and they exchanged the

${ }^{4}$ Greek Ioudaioi; in historical perspective, the word "Jews" is properly used only of persons in the Israelite tradition after the formation of the Jewish (Talmudic) kinship religion in the fifth century C.E.; see Malina and Rohrbaugh (1992:32-34).

5 By the Hellenistic period Israelite-Gentile marriages were considered "offering one's children to Molech" (Lev 18:21; 20:2), deserving the death penalty since such unions are "contrary to nature", as we shall note below. Paul's continued concern about Israel's purity laws can be seen in his assessment of offspring of a Jesus group member and an outsider, (1 Cor 7: 14). 
glory of the immortal God for images resembling a mortal human being or birds or four footed animals or reptiles" (Rom 1:18-23).

What is wrong with non-Israelites is that they do not worship the God of Israel, whom Judeans claim created the world (with Israel and Jerusalem at its centre). Paul now moves on to describe the behaviour typical of these idolaters, presumably not found among Israelites. It is this line of behaviour that reveals them as idolaters since their behaviour is a direct tit-for-tat (God "gave them up" to i.e. 1:24, 26, 28) outcome of idolatry:

"Therefore God gave them up in the lusts of their hearts to impurity, to the degrading of their bodies among themselves, because they exchanged the truth about God for a lie and worshiped and served the creature rather than the Creator, who is blessed forever! Amen. For this reason God gave them up to degrading passions. Their women exchanged natural intercourse for unnatural, and in the same way also the men, giving up natural intercourse with women, were consumed with passion for one another. Men committed shameless acts with men and received in their own persons the due penalties for their error. And since they did not see fit to acknowledge God, God gave them up to a debased mind and to things that should not be done. They were full with every kind of wickedness, evil, covetousness, malice. Full of envy, murder, strife, deceit, craftiness, they are gossips, slanderers, God haters, insolent, haughty, boastful, inventors of evil, rebellious toward parents, foolish, faithless, heartless, ruthless. They know God's decree, that those who practice such things deserve to die - yet they not only do them but even applaud others who practice them" (Rom 1: 24-32).

The "degrading" passions ${ }^{6}$ to which idolaters have been delivered by God include: (1) females (theleiai) exchanging natural (physike) sexual intercourse for what is against nature (para physin); and males (arsenes), giving up natural sexual (physike) intercourse with females, are consumed with passion for one another and receive in themselves their due penalty for their error; (2) debased minds, revealed in a list of deviant behaviours ${ }^{7}$.

6 "Degrading" of course points to a scale calibrated in terms of honor; see Gilmore (1987); Giovannini (1987); Malina and Neyrey (1991); Malina (1993); Neyrey (1998).

7 Recent treatments of this passage include: Hasitschka (1998); Stegemann (1998); Tiedemann (1998); for the Bible in general Nissinen (1998); popular presentations: Helminiak (1994); Penna (1997). 
Paul's opening categorisation of persons on the basis of gender was typical of the ancient Mediterranean, where the self was defined in terms of gender, genealogy, and geography (see Malina and Neyrey 1996). Gender derives from biological birth determined by God and fixed by God's creation. Genealogy derives from the kin group into which one was born, a fact determined by God in a structural arrangement fixed by God. Geography derives from the location of the social group of persons to which one's kin group belonged. Social groups included their physical environment, their sky, land, air, and water, all intimately bound together. Thus self, status, and social group defined who one was in antiquity.

For all Mediterraneans of antiquity the gendered self was essentially either male or female, each with nature-given, distinctive, genderbased social expectations (see Malina 1990; 1994):

MALE
active
dominant by nature
controlling
penetrating
seed bearing
concern for family honour
honour symboled by phallus
represents family to the
outside
like father like son

\author{
FEMALE \\ passive \\ subordinate by nature ${ }^{8}$ \\ controlled \\ penetrated \\ field, seed receiving \\ concern for family shame \\ shame symboled by hymen \\ represents family to the inside
}

like mother like daughter

While these gender expectations were common in the ancient Mediterranean world, here in Romans 1 Paul is concerned with the behaviour of females and males specifically in idolatrous societies, that is, outside Israelite society. Interpretations of his specific concerns often hinge on the word "natural". Females exchange natural intercourse for what is against nature, as do males. What does "nature" (physis) mean in firstcentury Hellenistic Greek? (There is no such term in Hebrew.) Perhaps it is best to begin with what it does not mean. It does not mean the area of concern of the "natural" sciences, the 100 percent sameness of all reality known through experimentation and laws of "nature" in physics, chemis-

8 The Israelite view is represented by Josephus: "for Scripture says: 'A woman is inferior to her husband in all things' [Gen 3:16]. Let her, therefore, be obedient to him; not so, that he should abuse her, but that she may acknowledge her duty to her husband; for God has given the authority to the husband" (Against Apion 2.201, Whiston). 
try, biology, and by analogy in sociology and psychology. This is "nature" as conceived by Descartes and the "new science" of Bacon and Vico. This perspective separated the empirical from the personal or spiritual laws of nature were the regularities of the empirical world, observable and testable and formulated, if possible, in the univocal language of mathematics.

For first-century Mediterraneans nature (physis) referred, first of all, to what was customary and usual: either for a given ethnos or people, a given series of animals, or even a given person or animal. In this sense the natural stood opposed to the conventional or legal, the behaviour decided upon by a person or group with legal power. The term also referred to what was usual in the qualities of all that existed, all creation what is instinctive, species-specific. What happened customarily and recurrently was natural, traceable to origins, to creation. Planets naturally moved erratically. Honey naturally tasted sweet. The word also referred to the genitals, male or female, and at times to the anal orifice (See Liddell-Scott ad verbum, Winkler 1990:217-20).

With reference to sexual relations there is an interesting passage in Artemidoros's Oneirocritica that offers a set of categories typical of early second-century Hellenism, perhaps earlier as well:

"In the section on sexual intercourse (sinousia), the best method of arrangement will be to consider firstly examples of sexual intercourse that is natural (kata physin), legal (kata nomon) and customary (kat' ethos); secondly examples of sexual intercourse that is illegal (para nomon); and thirdly examples of sexual intercourse that is unnatural" (para physin) (Oncirocritica I.78, White 58).

The groupings are pertinent, since in Romans Paul begins his categories with intercourse against nature followed by a list of behaviours, including intercourse, against law, here the law of Israel. What would such intercourse against nature include? While Paul specifies only two instances, Artemidoros observes that the sexual intercourse that is against nature is any sexual position apart from the frontal position, which is the only one "taught them (humans) by nature" (to de sygchrota monon hypo tes physeos didachthentes). The reason for this is that all species have a sexual position proper to themselves, and "humans have the frontal position as their proper one (anthropous to men oikeion schema to proschrota echein); they have devised the others when they gave in to insolence, dissipation and debauchery" (Oneirocritica I.79, White 63).

Thus a female's sexual intercourse against nature, as Artemidorus notes, includes all other positions, specifically those in which the female role is not passive (loc. cit.). This is in line with the Mediterranean gen- 
der concern that males are active and forceful, while females are passive and controlled. In this perspective, since males cannot engage in the frontal position with each other, their sexual relations have to be against nature.

If we follow Artemidoros, intercourse against convention or law (para nomon) is essentially incest of various types. Similarly oral sex is considered "doing the unmentionable" (arretopoiesthai). The Hellenistic sensibility was that persons doing oral sex cannot "share mouths", i.e., kiss or eat together (loc. cit., White 63-64). Paul too knows an unmentionable sexual relation, that of a male who marries his father's wife (1 Cor 5:1-2).

From where did anomalies such as females behaving like males or males behaving like females come? An explanation in Phaedrus's Fables (4.15), cited by Boyarin, accounts for "tribadic females and effeminate males" by recounting that Prometheus got drunk when making human beings and attached some male genitals to female people and some female genitals to male people by mistake. He concludes:

"To me it seems quite patent that the purport of the fable is that tribads are the men who got female genitals by mistake, and the molles are the women with male genitals attached to them. This actually provides beautiful evidence for Halperin's definition of sexuality as that modern cultural entity whose chief conceptual function "is to distinguish, once and for all, sexual identity from matters of gender - to decouple, as it were, kinds of sexual predilection from degrees of masculinity and femininity" (Halperin 1990:25). For Phaedrus it was impossible to imagine a woman loving women, so a lesbian must "really" be a man in a woman's body "by mistake" and this was, in one version or another, the most common way in Euro-America of accounting for same sex eroticism until the early twentieth century. Even Krafft-Ebing toward the end of the nineteenth century still conceived of lesbians as men with female bodies, i.e., as male souls in bodies with female genitalia" (Boyarin 1995:345 n 29).

Philo offers the view that, apart from boys used in pederasty, the passive partners in male sexual relations are actually androgynous persons who got that way either by birth or by continual same-gender sexual relations to the point of castrating themselves (Special Laws III.7.37-42). These passive partners demean male honour. For Greeks and Romans of the period it was precisely this demeaning of male honour, the denigration of male status, that made the passive male partner reprehensible (see Veyne 1998). 
Paul, in turn, shares a similar view, although he explicitly ascribes same-gender sexual relations to idolatry. For while Paul may have shared Hellenistic sensibilities, his ethnos (people) had its own ethos (customs) that supported the "us" against "them" boundary that controlled Paul and that Paul articulates. It seems this was the common viewpoint of firstcentury Israelites.

\section{CONCLUSION}

In Part 1 of the treatise "The New Testament and Sexuality?" basic introductory remarks on the prevalence of homosexuality in the New Testament era as compared to modern society are made. It is found that contemporary notions on homosexuality cannot be transposed back onto the thought world of Paul. In order to determine what Paul meant when he wrote Romans 1, and how it would have been received, Part 1 considered the social system behind Romans 1 .

The language Paul used is considered behind a Judean background primarily, though the orientation background is also Roman: The Jewish Christians in Rome lived in a Roman-Hellenistic world. The terms used in Paul's argument are analysed against their social-historic background. The complete argument, drawn in Part 2, indicates that Paul offers two sets of behaviour to demonstrate the wrath of God towards non-Israelites for their culpable idolatry. Behaviour is understood in light of either being in harmony with nature or in opposition to it.

\section{Consulted literature}

Artemidoros. 1963. Onirocriticon Libri V. RA Pack (ed). Leipzig: Tuebner.

-, 1975. The interpretation of dreams. RJ White (trans). Park Ridge: Noyes Press.

Charles, R H (ed) 1913. The Apocrypha and Pseudepigraphia of the Old Testament, Vol. II. Pseudepigraphia. Oxford: Clarendon Press.

Gilmore, D D 1987. The shame of dishonor, in: idem (ed.), Honor and shame and the unity of the Mediterranean. Special Publication of the American Anthropological Association 1987, 22: 2-21.

Giovannini, M J 1887. Chastity codes in the Circum-Mediterranean: Comparative perspectives, ibid. 61-74.

Greenblatt, S 1986. Fiction and friction, in: Heller, T C, Sosna, M \& Wellbery, D E (eds), Reconstructing individualism: Autonomy, Individuality and the self in Western thought. Stanford: Stanford University Press, 30-52; 329-32.

Halliday, M A K 1978. Language as social Semiotic: The social interpretation of language and meaning. Baltimore: University Park Press.

Halperin, D M 1990. One hundred years of homosexuality and other essays on Greek love. New York \& London: Routledge.

Hasitschka, M 1998. Homosexualität - eine Frage der Schöpfungsordnung, in: Zeitschrift für Neues Testament, 1998, 1, 2: 54-60.

Helminiak, D A 1994. What the Bible really says about homosexuality. San Francisco: Alamo Square. 
Josephus, Flavius. 1987. The Works of Josephus: New Updated Edition, Whiston W (transl). Peabody: Hendrickson.

Malina, B J 1986. Christian origins and cultural anthropology: Practical models for Biblical interpretation. Atlanta: John Knox.

-, 1990. Mary - Woman of the Mediterranean: Mother and Son, Biblical Theology Bulletin, 1990, 20: 54-64.

-, 1991. Reading theory perspective: Reading Luke-Acts, in: Neyrey. J H (ed), The Social World of Luke-Acts: Models for interpretation. Peabody: Hendrickson, 3-23.

-, 1993. The New Testament World: Insights from cultural anthropology. $2^{\text {nd }}$ Rev. Ed. Louisville: Westminster John Knox.

-, 1994. 'Let him deny himself' (Mark 8:34): A social psychological model of selfdenial, Biblical Theology Bulletin, 1994, 24: 106-19.

-, 1996. The social world of Jesus and the Gospels. London \& New York: Routledge.

Malina, B J \& Neyrey, J H, 1991. Honor and shame in Luke-Acts: Pivotal values of the Mediterranean world, in: Neyrey, J H (ed), The Social World of Luke-Acts: Models for interpretation. Peabody: Hendrickson, 25-65.

-, 1996. Portraits of Paul: An archaeology of ancient personality. Louisville: Westminster John Knox.

Malina, B J \& Rohrbaugh, R L 1992. Social-science commentary on the Synoptic Gospels. Minneapolis: Fortress.

Neyrey, J H. 1998. Honor and shame in the Gospel of Matthew. Louisville: West minster John Knox.

Nissinen, M 1998. Homoeroticism in the Biblical World: A historical perspective. Minneapolis: Fortress.

Penna, R 1997. Christian anthropology and homosexuality - 4: Homosexuality and the New Testament, Osservatore Romano, 1997, 5.

Philo, 1993. The works of Philo: New updated edition, Yonge, C D (transl), Peabody: Henderickson.

Pilch, J 1997. Psychological and Psychoanalytical approaches to interpreting the Bible in social-scientific context (BTB Readers Guide), Biblical Theology Bulletin, 1997, 27: 112-1.6.

Stegemann, W 1998. "Homosexualität - ein modernes Konzept, Zeitschrift für Neues Testament, 1998, 1, 2, 61-68.

Tiedemann, H 1998. Das Gesetz in den Gliedern - Paulus und das sexuelle Begehren, Zeitschrift für Neues Testament, 1998, 1, 2: 18-28.

Veyne, P 1998. Rome: Une Societé d'hommes, L 'Histoire, 1998, 221: 37.

Winkler, J 1990. The constraints of desire: The anthropology of sex and gender in Ancient Greece. New York \& London: Routledge. 